\title{
Effect of cigarette smoke exposure and mutant Kras overexpression on pancreatic cell proliferation
}

\author{
HOWARD P. GLAUERT ${ }^{1,2}$, R. SCOTT ELLIOTT ${ }^{1}$, SUNG GU HAN ${ }^{3}$, \\ MARK ATHEY ${ }^{1}$, EUN Y. LEE ${ }^{4}$ and C. GARY GAIROLA ${ }^{2}$ \\ ${ }^{1}$ Division of Nutritional Sciences, Department of Pharmacology and Nutritional Sciences; \\ ${ }^{2}$ Department of Toxicology and Cancer Biology, University of Kentucky, Lexington, KY 40536, USA; \\ ${ }^{3}$ Department of Food Science and Biotechnology of Animal Resources, Konkuk University, Seoul 05029, Republic of Korea; \\ ${ }^{4}$ Department of Pathology and Laboratory Medicine, University of Kentucky, Lexington, KY 40536, USA
}

Received March 11, 2015; Accepted September 28, 2016

DOI: 10.3892/ol.2017.5606

\begin{abstract}
Pancreatic cancer is the fourth leading cause of cancer-associated mortality. The major risk factor for pancreatic cancer is cigarette smoking. Kras mutations are commonly observed in human pancreatic cancers. The present study examined the hypothesis that exposure to cigarette smoke and overexpression of a mutant Kras gene in the pancreas affects pancreatic cell proliferation in mice. Mice overexpressing the mutant Kras gene (KRas ${ }^{\mathrm{G} 12 \mathrm{D}}$ ) in the pancreas as well as wild-type mice were exposed to environmental tobacco smoke for 2 weeks. Overexpression of mutant Kras increased cell proliferation in pancreatic ductal, acinar and islet cells. Notably, cigarette smoke exposure decreased cell proliferation in pancreatic ductal and acinar cells, and had no effect in islet cells. Cigarette smoke did not affect pancreatic protein levels of tumor necrosis factor (TNF) $\alpha$, p53, or cyclin $\mathrm{D}_{1}$, but mutant Kras overexpression slightly decreased TNF $\alpha$ and p53 protein levels. Therefore, pancreatic cell proliferation in mice overexpressing mutant Kras is associated with the later development of pancreatic tumors, but effects of cigarette smoke on pancreatic cell proliferation do not provide a good model for human pancreatic carcinogenesis.
\end{abstract}

\section{Introduction}

Pancreatic cancer is the tenth most common form of cancer, and is the fourth leading cause of cancer-associated mortality (1).

Correspondence to: Professor Howard P. Glauert, Division of Nutritional Sciences, Department of Pharmacology and Nutritional Sciences, University of Kentucky, 900 South Limestone Street, Lexington, KY 40536, USA

E-mail: hglauert@uky.edu

Abbreviations: ANOVA, analysis of variance; BrdU, bromodeoxyuridine; LSL, Lox-STOP-Lox; PanINs, pancreatic intraepithelial neoplasias; TNF, tumor necrosis factor

Key words: Kras, cigarette smoke, pancreas, cell proliferation
Pancreatic cancer is one of the deadliest forms of cancer, with a 5-year survival rate of only $4.4 \%$.

A number of risk factors have been identified for pancreatic cancer, including gender, ethnicity and history of chronic pancreatitis (2). The greatest environmental risk factor for pancreatic cancer is cigarette smoking (2). The relative risk for cigarette smoking is between 2 and 3 fold, but can be higher in heavy smokers, suggesting a dose-response association (2). It is not clear how cigarette smoke contributes to pancreatic cancer development. Components of cigarette smoke likely reach the pancreas through the general circulation, but also may come from the GI tract through reflux. The chemical component(s) of cigarette smoke that are responsible for increasing pancreatic cancer risk are not known, although some evidence supports a role for aromatic amines or $\mathrm{N}$-nitroso compounds (2). The molecular mechanisms of the enhancement of pancreatic cancer by cigarette smoke are not understood.

One approach to understanding the molecular mechanisms of pancreatic cancer development is to use animal models. Several chemical carcinogenesis models exist (3). A transgenic model has been developed, which uses an oncogenic Kras (KRas ${ }^{\mathrm{G} 12 \mathrm{D}}$ ) inserted into the endogenous Kras locus (4). The gene has a Lox-STOP-Lox (LSL) construct inserted upstream. These mice are interbred with mice containing the Cre recombinase downstream from a pancreatic specific promoter, either PDX-1 or P48. The PDX-1-Cre;LSL-KRas ${ }^{\text {G12D }}$ mice develop pancreatic intraepithelial neoplasias (PanINs), which progress over time (4). In addition, when these mice are crossed to mice containing p53 mutations or Ink4a/Arf deficiency, the rapid development of pancreatic adenocarcinomas is observed $(5,6)$.

The present study examined the hypothesis that exposure to cigarette smoke or overexpression of the oncogenic Kras oncogene would affect cell proliferation in the pancreas in mice. PDX-1-Cre; LSL-KRas ${ }^{\mathrm{G} 12 \mathrm{D}}$ and wild-type mice were exposed to cigarette smoke for 2 weeks. It has been observed previously that a 5-day exposure to cigarette smoke is sufficient to increase cell proliferation in the lung $(7,8)$. Mice were treated with bromodeoxyuridine (BrdU) during the exposure period, and the rate of cell proliferation and gene expression associated with cell proliferation were examined. 
Table I. Results of two-way analysis of variance for the study endpoints.

P-values

\begin{tabular}{lccc}
$\begin{array}{l}\text { Study } \\
\text { endpoint }\end{array}$ & $\begin{array}{c}\text { Main effect for } \\
\text { smoke exposure }^{\mathrm{a}}\end{array}$ & $\begin{array}{c}\text { Main effect for } \\
\text { Kras overexpression }^{\mathrm{b}}\end{array}$ & $\begin{array}{c}\text { Smoke/Kras } \\
\text { interaction }\end{array}$ \\
\hline Final body weight & 0.033 & 0.41 & 0.27 \\
Ductal cell LI & 0.016 & $<0.001$ & 0.12 \\
Acinar cell LI & 0.013 & $<0.001$ & 0.28 \\
Islet cell LI & 0.72 & $<0.001$ & 0.066 \\
TNF & 0.58 & 0.10 & 0.84 \\
P53 & 0.59 & 0.090 & 0.75 \\
Cyclin $\mathrm{D}_{1}$ & 0.39 & 0.38 & 0.89 \\
\hline
\end{tabular}

${ }^{\mathrm{a}} \mathrm{vs}$. non-smoke exposure group; ${ }^{\mathrm{b} v s}$. wild-type Kras expression group. LI, labeling index; TNF, tumor necrosis factor.

\section{Materials and methods}

Experimental design. PDX-1-Cre and LSL-KRAS ${ }^{\mathrm{G} 12 \mathrm{D}}$ mice were obtained from the National Cancer Institute Mouse Repository (Frederick, MD, USA). The two strains were bred to obtain 16 PDX-1-Cre; LSL-KRAS ${ }^{\text {G12D }}$ mice. PDX-1-Cre-positive mice were used as controls. Male 9-10 week old mice were used. Half of the mice in each group were exposed to cigarette smoke for a period of 2 weeks. In total, 7-8 mice were in each of the 4 groups, with a total of 30 mice. An inhalation exposure to smoke was performed in a whole-body Hinners type stainless steel/glass chamber, as previously described (9). Cigarette smoke was generated from 3R4F University of Kentucky (Lexington, KY, USA) research cigarettes. The concentration of smoke particulates in the exposure chamber atmosphere averaged $46 \pm 3 \mathrm{mg} \mathrm{TPM} / \mathrm{m}^{3}$. The mice received smoke exposure for a total of 6 h each day, 5 days per week, Monday to Friday, for 2 weeks (10 days total exposure). Mice were euthanized 3 days after the last exposure (the next Monday morning). Mice were administered BrdU in the drinking water $(0.5 \mathrm{mg} / \mathrm{ml})$, starting at the same time as smoke exposure, and continuing until they were euthanized. Subsequently, the pancreas was split into two pieces, with one half fixed in buffered neutral formalin (and subsequently processed to paraffin blocks) and the other half flash frozen in liquid nitrogen, and then stored at $-80^{\circ} \mathrm{C}$.

Analysis of cell proliferation. Subsequent to fixation and processing, 5- $\mu \mathrm{m}$ sections were prepared from the paraffin blocks. The sections of paraffin-embedded tissue samples were deparaffinized, thoroughly washed in water, and then placed in $3 \% \mathrm{H}_{2} \mathrm{O}_{2}$ in methanol for $10 \mathrm{~min}$. The sections were then stained immunohistochemically by the avidin-biotin-peroxidase complex method using Vectastain $\mathrm{ABC}$ reagent (Vector Laboratories, Burlingame, CA, USA), with mouse anti-BrdU monoclonal antibodies (cat. no. 555627; BD Biosciences, Franklin Lakes, NJ, USA), at $100 \mu \mathrm{l} /$ slide using a 1:40 dilution of BrdU. The reaction product was then visualized using diaminobenzidine (Vector Laboratories Peroxidase Substrate kit) and the slides were counterstained with hematoxylin. Having brown nuclei identified cells that had incorporated BrdU. Labeling indexes were determined for the following 3 regions in the pancreas: ductal, acinar and islet cells. In total, 500 cells per slide were counted and labeling indexes were determined.

Western blot analysis. Levels of tumor necrosis factor (TNF) a, p53 and cyclin D1 proteins in pancreas homogenates were determined by western analyses. Antibodies were obtained from Santa Cruz Biotechnology (Dallas, TX, USA). The frozen pancreases were homogenized in extraction buffer (Pierce Biotechnology, Inc., Rockford, IL, USA) containing protease inhibitors (Sigma-Aldrich; Merck Millipore, Darmstadt, Germany). Lysed tissue was centrifuged at 8,000 x $g$ for $30 \mathrm{~min}$ at $4^{\circ} \mathrm{C}$. Protein levels of the supernatants were determined by bicinchoninic acid assay (Pierce Biotechnology, Inc.) and stored at $-80^{\circ} \mathrm{C}$. Protein samples $(30 \mu \mathrm{g}$ per treatment) were separated using $10 \%$ SDS-PAGE and subsequently were transferred onto nitrocellulose membranes. Membranes were blocked with 5\% non-fat milk buffer and incubated overnight at $4{ }^{\circ} \mathrm{C}$ with primary antibodies. Subsequent to washing, membranes were incubated with secondary antibodies conjugated with horseradish peroxidase and visualized using enhanced chemiluminescence detection reagents (Thermo Fisher Scientific Inc., Waltham, MA, USA). Bands were quantified using ImageJ software (National Institutes of Health, Bethesda, MD, USA) and normalized to $\beta$-actin expression.

Statistical analysis. Results were first analyzed by two-way analysis of variance (ANOVA), using Sigmaplot for Windows (version 13.0; Systat Software, Inc., San Jose, CA). If significant interactions were identified, differences between means were determined using the Holm-Sidak post-hoc test. The results are reported as the mean \pm standard error of the mean. $\mathrm{P} \leq 0.05$ was considered to indicate a statistically significant difference. The results of the ANOVAs are shown in Table I.

\section{Results}

The present study examined the effects of mutant Kras overexpression and smoke exposure on pancreatic cell proliferation and associated gene expression. Mice were exposed to sidestream tobacco smoke for 2 weeks. Mutant Kras overexpression did not affect body weights, but short-term cigarette 

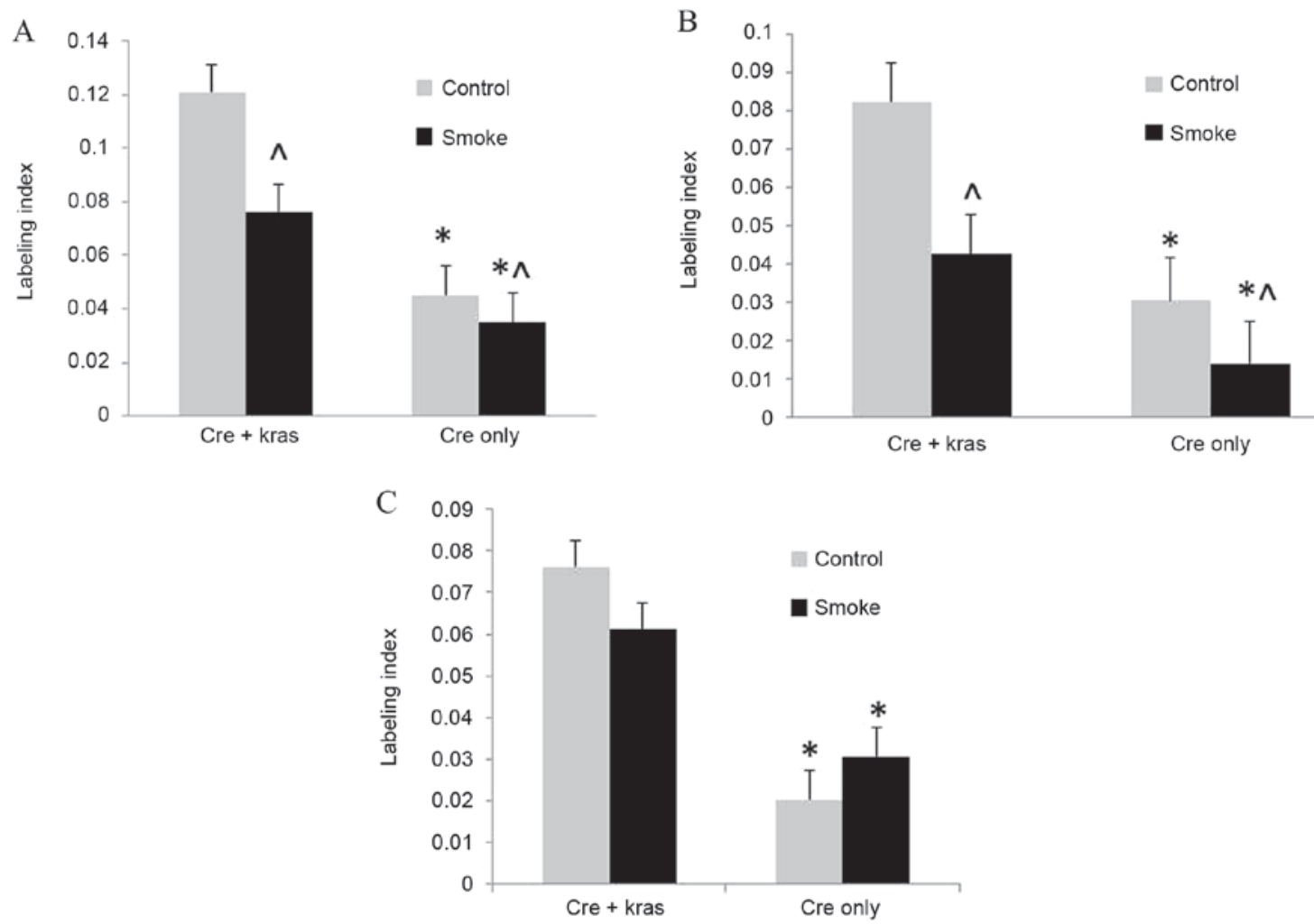

Figure 1. Labeling indices in pancreatic (A) ductal, (B) acinar and (C) islet cells. Results are expressed as the mean \pm standard error, with $n=7$ or 8 . "Significant differences due to mutant Kras overexpression are indicated with an asterisk; ${ }^{\wedge}$ significant differences in smoke-exposed mice $(\mathrm{P}<0.05)$. Cre, Cre recombinase.

A

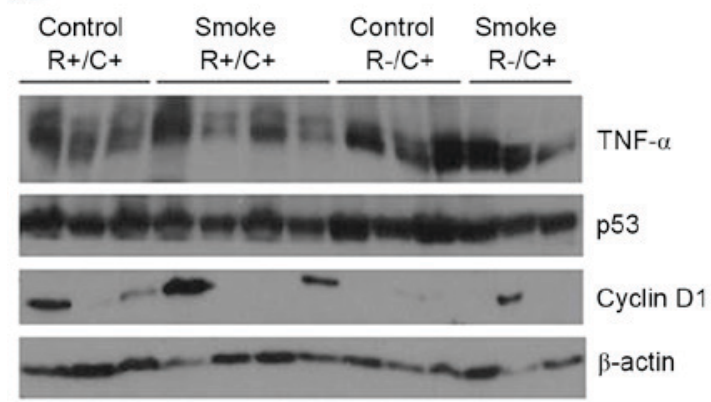

$\mathrm{C}$

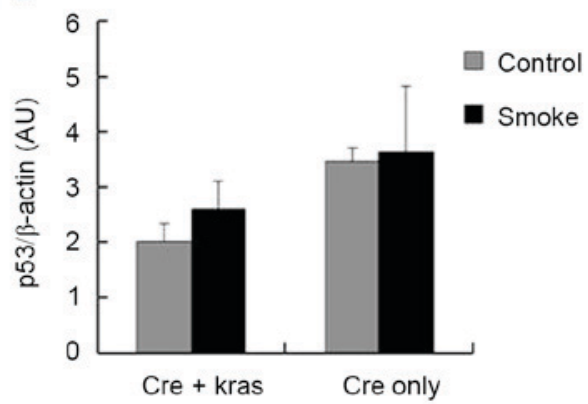

B

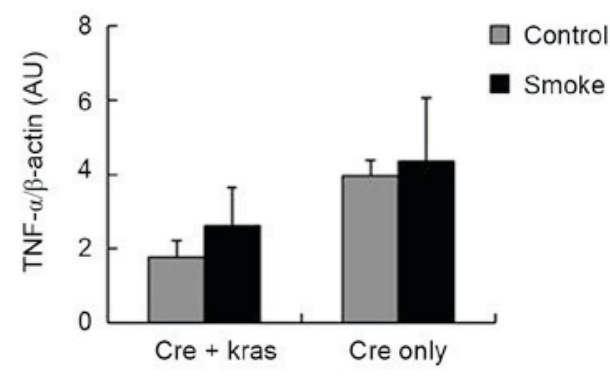

$\mathrm{D}$

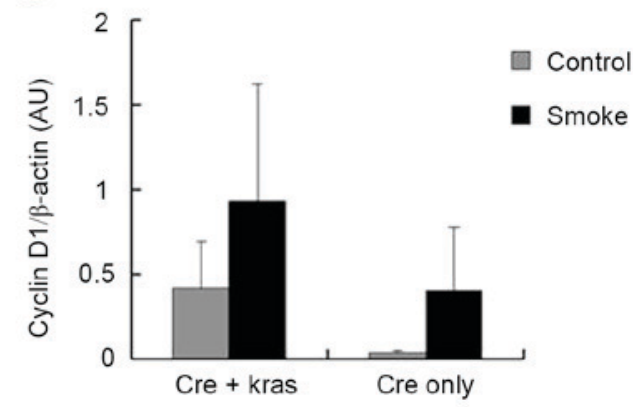

Figure 2. (A) The western blot analysis shows expression of TNF- $\alpha$, p53, cyclin D1 and $\beta$-actin in pancreas tissue lysates (A). The graphs show quantitative analysis of protein expression for (B) TNF- $\alpha,(\mathrm{C}) \mathrm{p} 53$, and (D) cyclin D1 using ImageJ. $\beta$-actin was used as the loading control. Results are expressed as the mean \pm standard error, with $n=3$ or 4 . TNF- $\alpha$, tumor necrosis factor $\alpha$; R, Kras; C/Cre, Cre recombinase; AU, arbitrary unit.

smoke exposure significantly reduced body weights $(\mathrm{P}=0.033$; data not shown). Mice were administered BrdU in the drinking water, and then labeling indexes of BrdU-stained nuclei were used to quantify cell proliferation. Cell proliferation in ductal 
cells, from which the majority of human pancreatic cancers are derived, was increased $(\mathrm{P}<0.001)$ in mice overexpressing mutant Kras; however, cigarette smoke exposure decreased $(\mathrm{P}=0.016)$ cell proliferation (Fig. 1). In acinar cells, cell proliferation was similarly increased $(\mathrm{P}<0.001)$ by mutant Kras overexpression and decreased $(\mathrm{P}=0.013)$ by cigarette smoke exposure. In islet cells, cell proliferation was increased $(\mathrm{P}<0.001)$ by mutant Kras overexpression, but not affected by cigarette smoke exposure.

Subsequently, the levels of several proteins in the pancreas that could be affecting cell proliferation and tumorigenesis were examined. TNF $\alpha$ is a pro-inflammatory cytokine that may have promoting or inhibitory effects in pancreatic carcinogenesis (10). p53 is a tumor suppressor gene that promotes apoptosis but also inhibits cell proliferation (11). Cyclin $\mathrm{D}_{1}$ regulates cyclin-dependent kinases (CDKs), which increase cell proliferation (12). Neither cigarette smoke exposure nor Kras overexpression, however, significantly affected the protein levels of $\mathrm{TNF} \alpha, \mathrm{p} 53$, or cyclin $\mathrm{D}_{1}$ in the pancreas (Fig. 2). Kras overexpression slightly, but not significantly, decreased the protein levels of TNF $\alpha(\mathrm{P}=0.10)$ and p53 $(\mathrm{P}=0.09)$.

\section{Discussion}

In the present study, it was observed that Kras overexpression increased but cigarette smoke exposure decreased cell proliferation in pancreatic ductal cells, the cell type from which most human pancreatic cancers are derived. It was observed that cigarette smoke induced decreases in cell proliferation in pancreatic ductal cells and acinar cells but had no effect in islet cells. A previous study has quantified cell proliferation in response to cigarette smoke; Wisniewska et al (13) observed inconsistent effects of cigarette smoke. Wisniewska et al (13), however, did not differentiate between the different types of pancreatic cells. Cigarette smoke was found not to promote 7,12-dimethylbenzanthracene-induced pancreatic carcinogenesis in mice (14). Cell proliferation was increased in the lung after short-term exposure to cigarette smoke in several studies $(7,8,15,16)$. In other studies examining cell proliferation in the pancreas, Xue et al (17) found that diets high in fat and phosphorus and low in calcium and vitamin D increased cell proliferation in pancreatic ductal and acinar cells. Ledda-Columbano et al (18) found that the administration of thyroid hormone increased cell proliferation in pancreatic acinar cells.

The present study observed that the expression of a mutant Kras oncogene in the pancreas increased cell proliferation in ductal, acinar and islet cells. The expression of this oncogene has previously been shown to induce PanINs and pancreatic tumors (4). The expression of the mutant Kras produces metabolic changes that are supportive of an increase in cell proliferation (19).

Neither Kras ${ }^{\text {G12D }}$ nor smoke exposure significantly affected the levels of three proteins that could affect cell proliferation. One factor could have been that whole pancreas was used in the analysis, which could have prevented the observation of changes in individual cell types. Kras ${ }^{\mathrm{G} 12 \mathrm{D}} \mathrm{s}$ inhibitory effect on p53 protein levels is consistent with the effect of p53 on increasing apoptosis but inhibiting cell proliferation (11). TNF $\alpha$ has been found to increase pancreatic cell proliferation $(20,21)$; therefore, it is not clear how Kras inhibition of TNF $\alpha$ contributes to the increase in cell proliferation observed in the mutant Kras mice.

In summary, the present mouse model does not appear to be a good model for cigarette smoke-induced human pancreatic carcinogenesis. Cigarette smoking is the number one environmental risk factor for human pancreatic cancer. Therefore, the inhibition of pancreatic ductal and acinar cell proliferation by smoke exposure in the present study is not associated with smoke effects on humans. It would be expected that decreased cell proliferation would be protective against pancreatic carcinogenesis.

\section{Acknowledgments}

The authors thank Ms. Ruth Holland and Mr. Chris Holland (both University of Kentucky) for technical assistance. This study was supported by the Institute for Science and Health (grant no. 09-1830-01RFA07) and the Kentucky Agricultural Experiment Station.

\section{References}

1. American Cancer Society: Cancer Facts and Figures. American Cancer Society, Atlanta, GA, 2015.

2. Li D and Jiao L: Epidemiology. In: Pancreatic Cancer. Von Hoff DD, Evans DB and Hruban RH (eds.). Jones and Bartlett Publishers, Sudbury, MA, pp103-112, 2005.

3. Grippo PJ and Sandgren EP: Modeling pancreatic cancer in animals to address specific hypotheses. In: Methods in Moleculear Medicine, Vol.103. Pancreatic Cancer: Methods and Protocols. Su G (ed.) Humana Press, Totowa, NJ, pp217-243, 2005.

4. Hingorani SR, Petricoin EF, Maitra A, Rajapakse V, King C, Jacobetz MA, Ross S, Conrads TP, Veenstra TD, Hitt BA, et al: Preinvasive and invasive ductal pancreatic cancer and its early detection in the mouse. Cancer Cell 4: 437-450, 2003.

5. Hingorani SR, Wang L, Multani AS, Combs C, Deramaudt TB, Hruban RH, Rustgi AK, Chang S and Tuveson DA: Trp53R172H and KrasG12D cooperate to promote chromosomal instability and widely metastatic pancreatic ductal adenocarcinoma in mice. Cancer Cell 7: 469-483, 2005.

6. Aguirre AJ, Bardeesy N, Sinha M, Lopez L, Tuveson DA, Horner J, Redston MS and DePinho RA: Activated Kras and Ink4a/Arf deficiency cooperate to produce metastatic pancreatic ductal adenocarcinoma. Genes Dev 17: 3112-3126, 2003.

7. Witschi H, Oreffo VI and Pinkerton KE: Six-month exposure of strain A/J mice to cigarette sidestream smoke: Cell kinetics and lung tumor data. Fundam Appl Toxicol 26: 32-40, 1995.

8. Li J, Tharappel JC, Han SG, Cantor AH, Lee EY, Gairola CG and Glauert HP: Effect of dietary selenium and cigarette smoke on pulmonary cell proliferation in mice. Toxicol Sci 111: 247-253, 2009.

9. Gairola CG: Animal models of 2nd hand smoking. In: Molecular Mechanisms for Tobacco-Induced Diseases. Wang XL and Scott D (eds.) Nova Science Publishers, New York, NY, pp121-132, 2006

10. Chopra M, Lang I, Salzmann S, Pachel C, Kraus S, Bäuerlein CA, Brede C, Garrote AL, Mattenheimer K, Ritz M, et al: Tumor necrosis factor induces tumor promoting and anti-tumoral effects on pancreatic cancer via TNFR1. PLoS One 8: e75737, 2013.

11. Kruiswijk F, Labuschagne CF and Vousden KH: p53 in survival, death and metabolic health: A lifeguard with a licence to kill. Nat Rev Mol Cell Biol 16: 393-405, 2015.

12. Kim JK and Dieh1 JA: Nuclear cyclin D1: An oncogenic driver in human cancer. J Cell Physiol 220: 292-296, 2009.

13. Wisniewska E, Dylik A, Kulza M, Florek E, Piekoszewski W, Seńczuk-Przybyłowska M and Marszałek A: Exposure to ethanol and tobacco smoke in relation to level of PCNA antigen expression in pancreatic and hepatic rat cells. Pharmacol Rep 65: 914-926, 2013. 
14. Bersch VP, Osvaldt AB, Edelweiss MI, Schumacher Rde C, Wendt LR, Abreu LP, Blom CB, Abreu GP, Costa L, Piccinini P and Rohde L: Effect of nicotine and cigarette smoke on an experimental model of intraepithelial lesions and pancreatic adenocarcinoma induced by 7,12-dimethylbenzanthracene in mice. Pancreas 38 : 65-70, 2009.

15. March TH, Kolar LM, Barr EB, Finch GL, Ménache MG and Nikula KJ: Enhanced pulmonary epithelial replication and axial airway mucosubstance changes in F344 rats exposed short-term to mainstream cigarette smoke. Toxicol Appl Pharmacol 161: 171-179, 1999.

16. Zhong CY, Zhou YM, Douglas GC, Witschi $\mathrm{H}$ and Pinkerton KE: MAPK/AP-1 signal pathway in tobacco smoke-induced cell proliferation and squamous metaplasia in the lungs of rats. Carcinogenesis 26: 2187-2195, 2005.

17. Xue L, Lipkin M, Newmark H and Wang J: Influence of dietary calcium and vitamin D on diet-induced epithelial cell hyperproliferation in mice. J Natl Cancer Inst 91: 176-181, 1999.
18. Ledda-Columbano GM, Perra A, Pibiri M, Molotzu F and Columbano A: Induction of pancreatic acinar cell proliferation by thyroid hormone. J Endocrinol 185: 393-399, 2005.

19. Bryant KL, Mancias JD, Kimmelman AC and Der CJ: KRAS: Feeding pancreatic cancer proliferation. Trends Biochem Sci 39: 91-100, 2014.

20. Song SY, Gannon M, Washington MK, Scoggins CR, Meszoely IM, Goldenring JR, Marino CR, Sandgren EP, Coffey RJ Jr, Wright CV and Leach SD: Expansion of $\mathrm{Pdx} 1$-expressing pancreatic epithelium and islet neogenesis in transgenic mice overexpressing transforming growth factor alpha. Gastroenterology 117: 1416-1426, 1999.

21. Egberts JH, Cloosters V, Noack A, Schniewind B, Thon L, Klose S, Kettler B, von Forstner C, Kneitz C, Tepel J, et al: Anti-tumor necrosis factor therapy inhibits pancreatic tumor growth and metastasis. Cancer Res 68: 1443-1450, 2008. 